\title{
Electrochemical Properties of Modified Carbon Paste with Copper Hexacyanoferrate Film on Nitric Oxide Reduction
}

\author{
Liridon Berisha', Arsim Maloku1', Eduard Andoni' ${ }^{2}$, Tahir Arbneshi' \\ ${ }^{1}$ Departament of Chemistry, Faculty of Mathematical and Natural Science, University of Prishtina, Prishtina, \\ Kosovo \\ ${ }^{2}$ Departament of Chemistry, Faculty of Natural Sciences, University of Tirana, Tirana, Albania \\ Email: tahir.arbneshi@uni-pr.edu
}

Received 26 February 2014; revised 28 March 2014; accepted 6 April 2014

Copyright (C) 2014 by authors and Scientific Research Publishing Inc.

This work is licensed under the Creative Commons Attribution International License (CC BY).

http://creativecommons.org/licenses/by/4.0/

(c) (i) Open Access

\begin{abstract}
Copper hexacyanoferate film was prepared electrochemically on carbon paste electrode and was tested for detection of nitric (II) oxide in comparison with unmodified electrodes. Modified electrode could be operated under physiological conditions ( $\mathrm{pH}$ 7.5, $0.1 \mathrm{M}$ phosphate buffer), with an operating potential of $\mathbf{- 4 0 0} \mathbf{~ m V}$ (vs. $\mathbf{A g} / \mathrm{AgCl}$ ) in hydrodynamic amperometry. The amperometric response of the electrode showed good linearity up to $250 \mu \mathrm{M}$ with a detection limit $(3 \sigma)$ of 8.32 $\mu \mathrm{M}$. The relative standard deviation for the repeatability of measurements for $100 \mu \mathrm{M}$ nitric (II) oxide was $4.1 \%$ ( $n=10$ measurements) and the corresponding reproducibility was $14 \%$ ( $n=5$ electrodes). The effect of investigated interferences (nitrite and nitrate ion) was not fatal and could be eliminated using the standard addition method. The modified electrode also seems promising to detect NO in car exhaust fumes.
\end{abstract}

\section{Keywords}

Sensor, Nitric Oxide, Copper-Hexacyanoferrate, Electrocatalytic, Carbon Paste Electrode

\section{Introduction}

Carbon paste electrode (CPE) is a very useful material on electrochemical analysis, because of its biocompatibility for in vivo measurements [1]. As an electrode material it is very simple to prepare and handle, and an easy bulk modification with different mediators makes it more useful in electroanalysis for different analytes [2]. Using mediators on carbon paste electrodes is very important, because they may have electrocatalytic effects on 
analyte redox reaction. Decreasing overpotential of analyte at electrode is very important for its application. The working potential of electrode in amperometric sensors affects the deterioration of measurements on real samples, causing secondary redox reactions with sample matrix, especially nitrite and nitrate ions, which are oxidation products of nitric (II) oxide [3].

The determination of NO is not a simple task because of its high reactivity; the half-life of nitric oxide in physiological conditions is around 5 seconds; therefore the required analytical methods for its spatial detection must have rapid response time [4]. Some of its physiological and pathophysiological effects are smooth muscle relaxation, inhibition of platelet activation, neurotransmission, immune response respectively cardiovascular diseases [5] etc.

The different modifiers were investigated on their ability to decrease the overpotential of nitric oxide on different electrode materials, such as nickel phtalocyanine, which has a catalytic effect on the NO oxidation [6] [7].

Carbon paste electrode was modified in different ways, for example, to increase its catalytic effect on oxidation of nitric (II) oxide using chromium (III) oxide [8], ruthenium (IV) oxide [9]. Also some different complex compounds were used, because of their ability to have a catalytic effect on nitric oxide overpotential such as nickel (II) hexacyanoferrate [10], indium hexacyanoferrate [11] phenylendiamine [12] and poly(thionine)/Nafion [13], carbon nanotube [14] silver nanoparticles/Hemoglobin as a biosensor recognition site [15].

The copper hexacyanoferrate electrocatalytic effects were confirmed for hydrogen peroxide [16], ascorbic acid [17] and nitrite ions [18]. It was also characterized for redox-mediated biosensors, as a modifier of carbon film electrodes [19] and it was successfully applied on carbon paste enzyme electrodes for glucose sensors [20]. The aim of the presented work was to improve a new modification method with copper hexacyanoferrate formed by reduction of copper on carbon paste electrode. CuHCF film was prepared using consecutive cyclic voltammetry in hexacyanoferrate ion solution of CPE-Cu film. The investigation of CuHCF film stability and electrocatalytic effect on nitric (II) oxide reduction demonstrated that carbon paste electrode modified with CuHCF works on lower potential compared to other sensors.

\section{Experimental}

\subsection{Chemicals, Reagents and Solutions}

All used chemicals were analytical reagent grade. Sulfanilamide, N-(1-naphtyl)-ethylene diamine, copper sulphate pentahydrate, potassium hexacyanoferrate (III), Nafion ${ }^{\circledR}$ (5\% m:m solution in lower aliphaic alcohols) were obtained from Sigma. Phosphate buffer solution (PBS) was prepared by mixing aqueous solutions of sodium dihydrogen phosphate $(0.1 \mathrm{~mol} / \mathrm{L})$ and disodium hydrogen phosphate $(0.1 \mathrm{~mol} / \mathrm{L})$ until the required $\mathrm{pH}$ was achieved. A nitric oxide stock solution was prepared by bubbling NO produced by the reaction of a saturated aqueous solution of sodium nitrite with $2 \mathrm{M}$ sulfuric acid (Equation (1)), through a $4 \mathrm{M}$ potassium hydroxide solution and finally collecting it in phosphate buffer solution (0.1 M, pH 7.5).

$$
6 \mathrm{NaNO}_{2}+3 \mathrm{H}_{2} \mathrm{SO}_{4} \rightarrow 4 \mathrm{NO}+2 \mathrm{H}_{2} \mathrm{O}+3 \mathrm{Na}_{2} \mathrm{SO}_{4}+2 \mathrm{HNO}_{3}
$$

First, all the apparatus for NO gas production was deaerated with nitrogen gas for 30 minutes. The standard stock solution was freshly prepared before the use. The concentration of NO in the stock solution was determined using sulfanilamide and N-(1-naphtyl)-ethylenediamine as described in [21]. Sodium nitrite and nitrate stock solution $(0.1 \mathrm{M})$ were freshly prepared before the use.

\subsection{Apparatus}

The potentiostat Autolab PSTAT 10 with software GPES version 4.9 and a potentiostat PalmSens with software PSTrace were used for cyclic voltammetry and hydrodynamic amperometry. The electrochemical cell consisted of a carbon paste electrode as the working electrode, an $\mathrm{Ag} / \mathrm{AgCl} / 3 \mathrm{M} \mathrm{KCl}$ reference electrode (Metrohm 6.0733.100), and a platinum wire as the counter electrode. Nitrogen was used for degassing the solutions. A magnetic stirrer provided convection of the solution. All potentials mentioned in this paper are referred to the $\mathrm{Ag} / \mathrm{AgCl}$ reference electrode. The flow injection system was assembled from a potentiostat as the detector, a high performance liquid chromatographic pump (1100 ICI instruments), a sample injection valve (5020 Rheodyne, Cotati, CA, USA), and a thin layer electrochemical detector (LC 4C, BAS, West Lafayette, Indiana, USA) with a flow through cell (spacer thickness $0.19 \mathrm{~mm}$; CC-5, BAS). 


\subsubsection{Preparation of Working Electrodes}

Unmodified carbon paste was prepared by mixing 1.000 g graphite powder and $360 \mu \mathrm{L}$ paraffin oil (Uvasol ${ }^{\circledR}$, $0.84-0.89 \mathrm{~kg} / \mathrm{L}$,) in an agate mortar by gently stirring with a pestle until uniformity and proper compactness was obtained.

Modified carbon paste electrode was prepared by electrodeposition of copper at $-0.40 \mathrm{~V}$ v.s. $\mathrm{Ag} / \mathrm{AgCl}(3 \mathrm{M})$ for $60 \mathrm{~s}$, after that electrode was immersed on potassium hexacyanoferrate solution $1 \mathrm{mM}$ and scanned in cyclic voltammetry for 20 cycles until no difference was mention on peak currents. The prepared film electrode of copper-hexacyanoferrate was stabilized on phosphate buffer $0.1 \mathrm{M} \mathrm{pH} 7.5$ with 5 scans and electrode was stored on phosphate buffer.

\subsubsection{Procedures}

Cyclic voltammograms were scanned between 900 and $-700 \mathrm{mV}$ with a scan rate of $50 \mathrm{mV} / \mathrm{s}$, unless stated otherwise. Hydrodynamic amperometric measurements were made at operating potentials of $-400 \mathrm{mV},-300 \mathrm{mV},-200$ $\mathrm{mV},-100 \mathrm{mV}$ and $0 \mathrm{mV}$ if not mentioned otherwise; NO stock solution $(0.50-4.00 \mathrm{~mL})$ was added per step.

\section{Results and Discussion}

The copper electro deposition parameters are very important, because they effect on electrode response. Copper film (Cu-film) was prepared with potentiostatic method in $10 \mathrm{mM}$ copper solution, using carbon paste electrode, as a working electrode. To find best time of $\mathrm{Cu}$-film deposition (Figure 1), we compared Cu-film electrode response at $-0.20 \mathrm{~V}$ to nitric oxide for different deposition time. The deposition time of $60 \mathrm{sec}$. was chosen because better results are achieved compared to the other deposition times. The longer deposition time produces bad film compactness and stability of an electrode. The electro deposition time of 30 seconds shows higher signal value but the problems were with adding hexacyanoferrate film electrochemically. To select the potential of the electro deposition $-0.70 \mathrm{~V}$ vs. $\mathrm{Ag} / \mathrm{AgCl}(3 \mathrm{M})$ was not conducive because it did not give a repeatable response to analyte compared to the electro deposition potential of $-0.40 \mathrm{~V}$. Also, the copper hexacyanoferrate film was stable after copper deposition at $-0.40 \mathrm{~V}$, and gives higher signal to NO.

\subsection{Cyclic Voltammetry}

Carbon paste electrode modified with Cu-film electrode was tested on cyclic voltammetry in phosphate buffer solution 0.1 M (pH 7.5). In Figure 2, it is shown that cyclic voltammogram of CPE-Cu film electrode can be noticed at potential of $-0.20 \mathrm{~V}$ copper (II) reduction and around $0.0 \mathrm{~V}$ oxidation reaction of $\mathrm{Cu}^{\circ}$ to $\mathrm{Cu}$ (II) and copper oxide film is produced in the electrode surface.

Cyclic voltammogram with scan rate of $5 \mathrm{mV} / \mathrm{s}$ of Cu-film electrode is shown in Figure 3, where can be seen

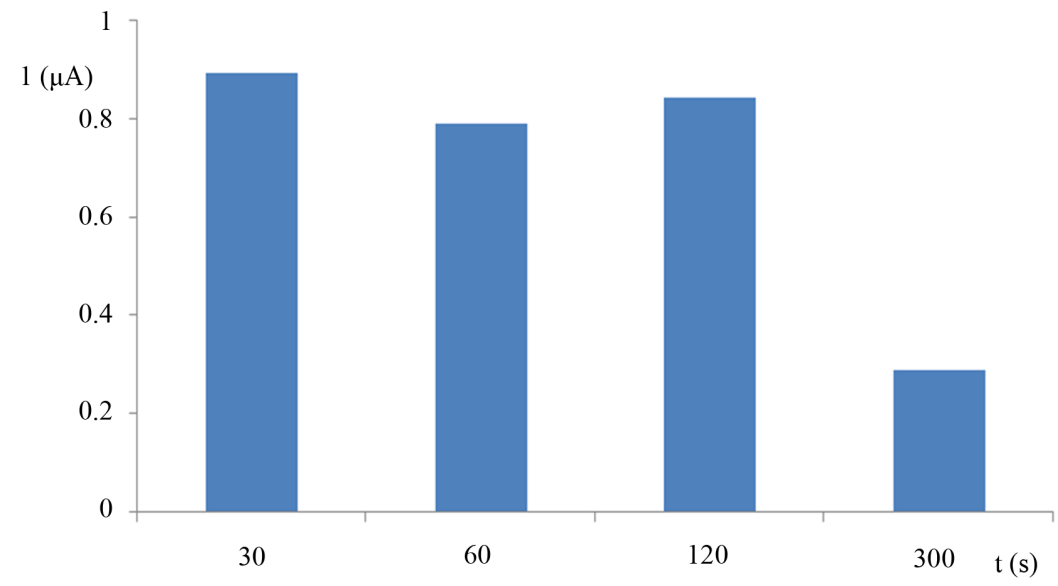

Figure 1. Response of electrode modified with copper film with different deposition time to NO $50 \mu \mathrm{M}$ in flow injection system, operating potential $-0.20 \mathrm{~V}$, flow rate $0.40 \mathrm{~mL} / \mathrm{min}$, injection volume $200 \mu \mathrm{L}$, carrier $0.1 \mathrm{M}$ phosphate buffer $\mathrm{pH} 7.5$. 


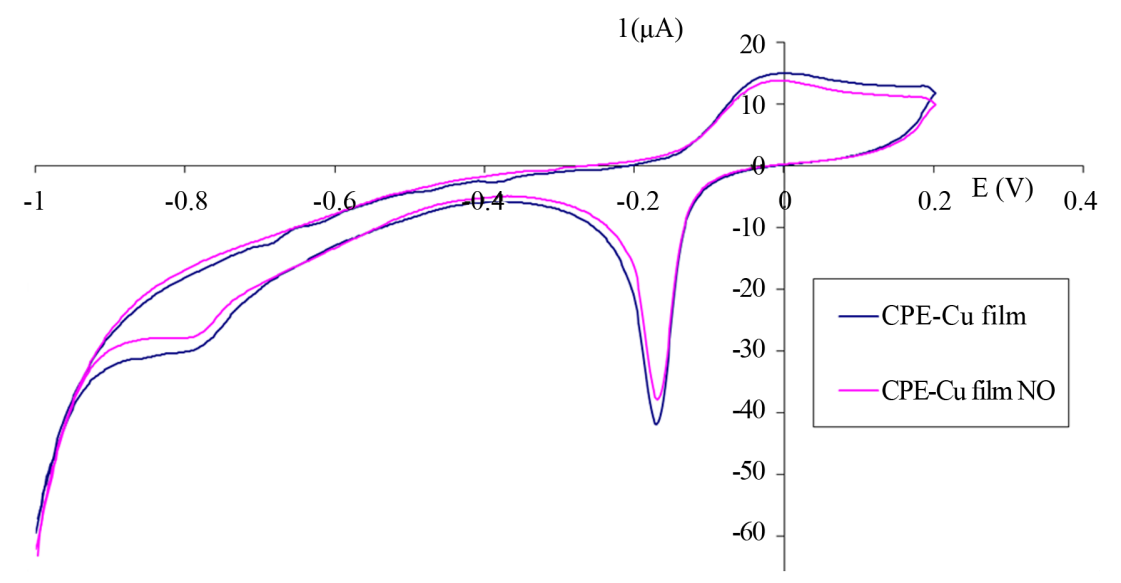

Figure 2. Cyclic voltammograms of a modified CPE with Cu-film before and after the addition of $50 \mu \mathrm{mol} / \mathrm{L}$ NO scan rate $50 \mathrm{mV} / \mathrm{s}$, phosphate buffer $0.1 \mathrm{M}, \mathrm{pH}$ 7.5.

two steps of copper (II) reduction, $\mathrm{Cu}(\mathrm{II}) \rightarrow \mathrm{Cu}(\mathrm{I})$ and $\mathrm{Cu}(\mathrm{I}) \rightarrow \mathrm{Cu}^{\circ}$, peak potentials at $-0.10 \mathrm{~V}$ respectively $-0.20 \mathrm{~V}$. These peaks may be shown because of complex compound formation in electrode surface with phosphate ion in solution.

Copper film electrode was covered with hexacyanoferrate using cyclic volatmmetry. The copper hexacyanoferrate film was prepared at $0.1 \mathrm{M}$ potassium nitrate solution containing $1 \mathrm{mM}$ potassium hexacyanoferrate. Numbers of cyclic voltammetric scans were around 20, until no significant difference was noticed of hexacyanoferrate redox peaks between the last two scans.

The reduction and oxidation peaks at potential $0.50 \mathrm{~V}$ and $0.80 \mathrm{~V}$ are peaks of redox reactions of iron hexacyanoferrate $\mathrm{Fe}^{\mathrm{III}} \Leftrightarrow \mathrm{Fe}^{\mathrm{II}}$. The peak potential at -0.40 and $0.0 \mathrm{~V}$ corresponds to the conversion of copper from its oxidation state +2 and 0 .

Based on cyclic voltammetric scans (Figure 4), can be concluded that copper hexacyanoferrate complex compound is formed because the oxidation and reduction peak is going to increase after every scan. Copper hexacyanoferrate (II) complex is insoluble; the produced film in the surface electrode is stable in aqua media. Copper (II/I) reduction peak at $-0.40 \mathrm{~V}$ is increased after every scan and the concentration of oxidized copper near electrode surface is going to be higher, because its oxidized state produces complex compound with hexacyanoferrate (II). The decrease of oxidation peak intensity is attributed to metallic copper from Cu-film. This happens because the metallic form in the surface electrode is going to decrease after every scan, because the copper exists in oxidized form as copper (II) complex with hexacyanoferrate.

Carbon paste electrode modified with copper hexacyanoferrate film was tested on $0.1 \mathrm{M}$ phosphate buffer solution pH 7.5 for its response to nitric (II) oxide (Figure 5). After the addition of nitric (II) oxide, cathodic current is increased near reduction peak of copper because of the electrocatalytic effects of copper (II) hexacyanoferrate. The suggested reaction mechanism (Figure 6) assumes the chemical oxidation of copper hexacyanoferrate by NO and produce of nitrosyl ciano complex compound which returns electrochemically to the reduced form, at the electrode surface. At positive potential above $0.75 \mathrm{~V}$ the oxidation current is increased because of NO oxidation at electrode.

\subsection{Hydrodynamic Amperometry}

The modified electrode with copper hexacyanoferrate film was tested for its response to different concentration of nitric oxide solutions. The modified electrode shows linearity up to concentration $250 \mu \mathrm{M}$, with sensitivity $5.696 \mathrm{nA} / \mu \mathrm{M}$ and correlation factor 0.994 (Figure 7).

The detection limit $(3 \sigma)$ calculated from standard deviation in hydrodynamic amperometry for $43.7 \mu \mathrm{M}$ solution of NO was $8.32 \mu \mathrm{M}(\mathrm{SD}=15.8$, average $219.4 \mathrm{nA})$.

The main interferent compounds may come from nitrite and nitrate ions, which are also the reaction products of NO oxidation, and other compounds that are present in real samples. To avoid interferences we used sulfonil polyfluorotetraethylene $\left(\mathrm{Nafion}^{\circledR}\right)$ membrane. This anionic membrane contains negatively charged sulfonyl 


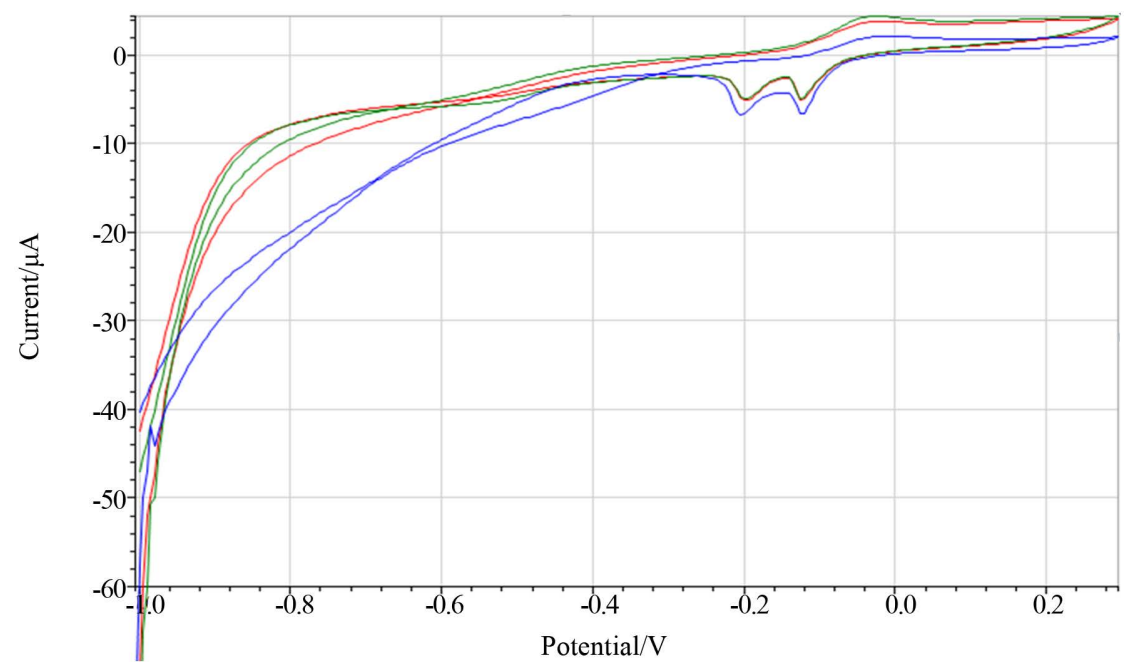

Figure 3. Cyclic voltammograms of a modified CPE with Cu-film before $(-)$ and after the addition of $20 \mu \mathrm{mol} / \mathrm{L}(-)$ and $30 \mu \mathrm{mol} / \mathrm{L}(-)$ NO scan rate $5 \mathrm{mV} / \mathrm{s}$, phosphate buffer $0.1 \mathrm{M}$, $\mathrm{pH} 7.5$.

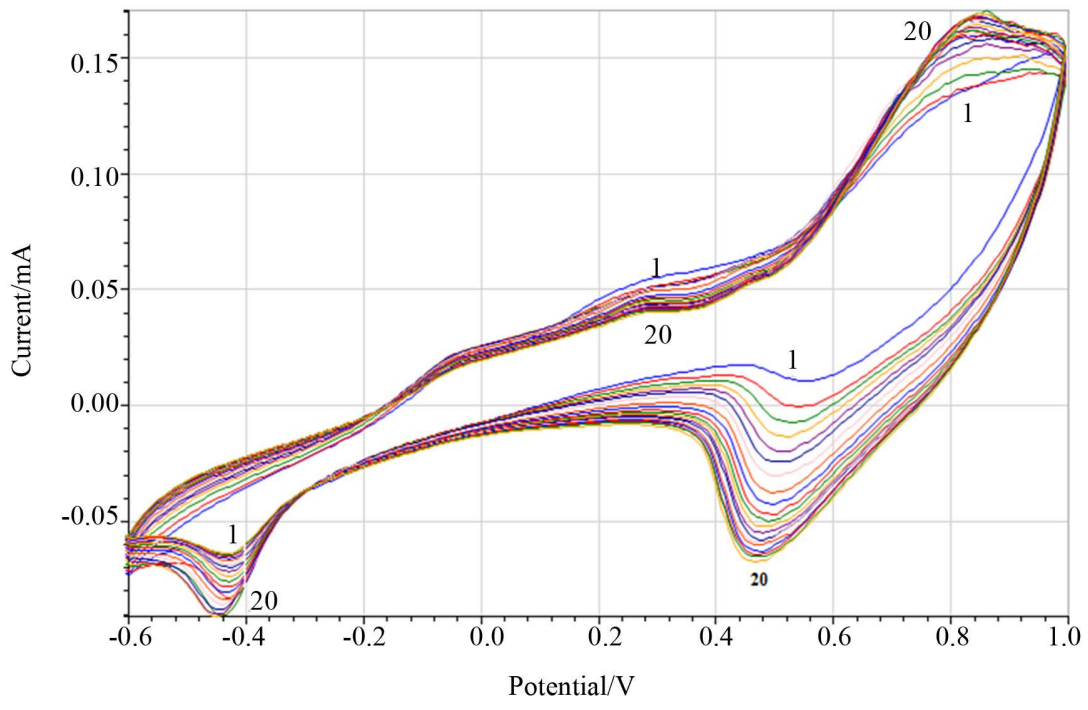

Figure 4. Cyclic voltammograms of a modified $\mathrm{CPE} \mathrm{Cu}-\mathrm{film}$ in $1 \mathrm{mM}$ potassium hexacyanoferrate scan rate $100 \mathrm{mV} / \mathrm{s}$, potassium nitrate 0.1 , no. scans 20 .

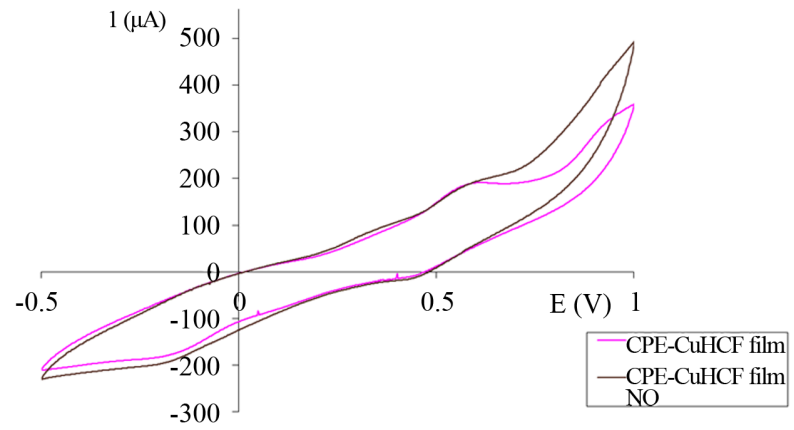

Figure 5. Cyclic voltammograms of a modified CPE with $\mathrm{Cu}$ HCF-film before and after the addition of $50 \mu \mathrm{mol} / \mathrm{L}$ NO scan rate $50 \mathrm{mV} / \mathrm{s}$, phosphate buffer $0.1 \mathrm{M}, \mathrm{pH} 7.5$. 
groups which prevent penetration of negatively charged ions to electrode surface. The neutralized Nafion solution was diluted with alcohol, and the electrode surface was covered with $10 \mu \mathrm{L}$.

Based on the results shown in Figure 8, the electrode does not show measurable signal for nitrite and nitrate ions except on $0 \mathrm{~V}$ the signal intensity was $-1 \mathrm{nA}$ and $-28 \mathrm{nA}$ for $\mathrm{NO}_{2}^{-}$respectively $\mathrm{NO}_{3}^{-}$. As expected, the signal for nitric (II) oxide solution is decreased because of covered surface with polyfluorotetraethylene memane. Nafion membrane is penetrable of NO molecule, but it covers physically the electroactive sites of electrode surface.

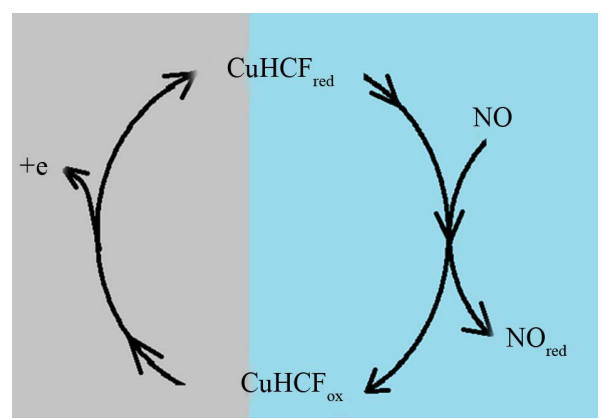

Figure 6. Suggested reaction mechanism of the electro-catalytic action of CuHCF on nitric (II) oxide reduction.

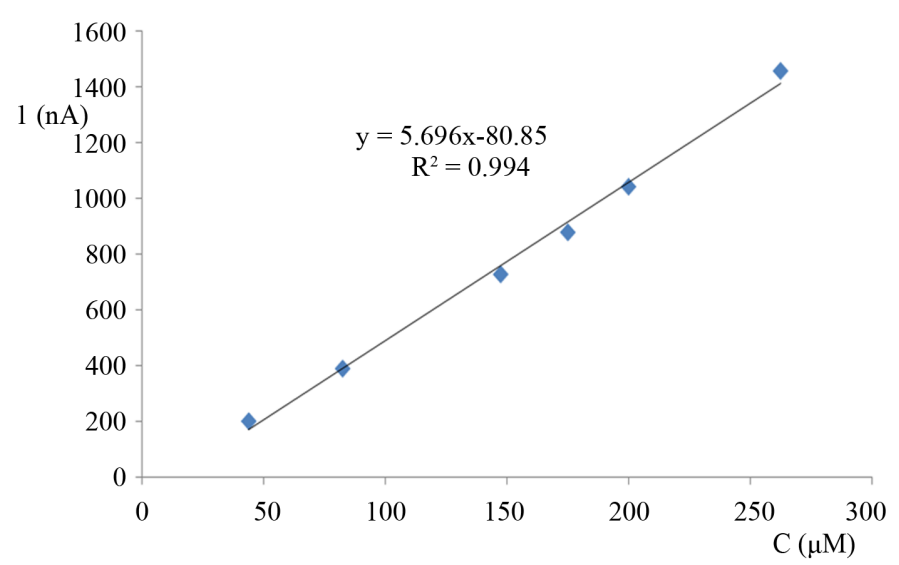

Figure 7. Calibration curve of a modified CPE with $\mathrm{Cu}$ HCF-film in different concentration of NO in hydrodynamic amperometry mode, operating potential $-0.40 \mathrm{~V}$ (cathodic current).

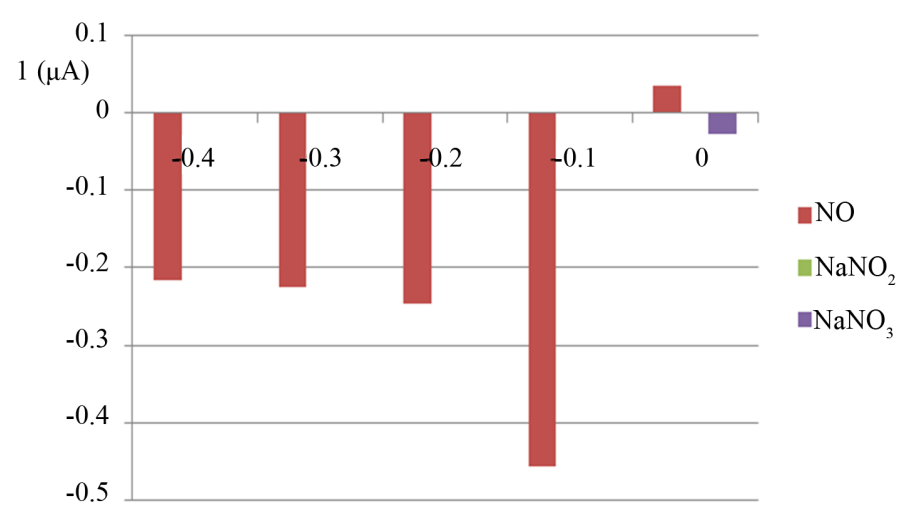

Figure 8. Signal intensity for $300 \mu \mathrm{M}$ NO, $1 \mathrm{mM} \mathrm{NaNO}$ and $1 \mathrm{mM}$ $\mathrm{NaNO}_{3}$ at potential $-0.40,-0.30,-0.20,-0.10$, and $0.0 \mathrm{~V}$ at CuHCF modified electrode coverd with Nafion membrane. 


\section{Conclusion}

Carbon paste electrode modified with copper hexacyanoferrate as an electrocatalytic mediator exhibit improved performance for the determination of nitric oxide, compared to unmodified electrodes, because the modifier lowers the over-potential and increases the sensitivity for the electrochemical reduction of the analyte. The reaction mechanism involves the reaction of copper $\mathrm{Cu}^{\circ}(\mathrm{I} / \mathrm{II})$ and iron of hexacyanoferrate ion $\mathrm{Fe}(\mathrm{II} / \mathrm{III})$. The suggested reaction mechanism assumes the chemical oxidation of copper $\mathrm{Cu}^{\circ} \diamond \mathrm{Cu}$ (I/II) or iron $\mathrm{Fe}(\mathrm{II}) \diamond \mathrm{Fe}$ (III) by NO producing nytrosyl complex compound. This nytrosyl ciano complex is electrochemically reduced at electrode. The modified electrode has a good stability and high sensitivity which can be exploited for the determination of nitric oxide in hydrodynamic amperometry. The new chemical sensor also seems promising to detect NO in car exhaust fumes.

\section{References}

[1] Svancara, I., Kalcher, K., Walcarius, A. and Vytras, K. (2012). Electroanalysis with Carbon Paste Electrodes. CRC Press, 163.

[2] Beyene, N.W., Kotzian, P., Schachl, K., Alemuc, H., Turkušic, E., Copra, A., Moderegger, H., Švancara, I., Vytras K. and Kalcher, K. (2004) (Bio)Sensors Based on Manganese Dioxide-Modified Carbon Substrates: Retrospections. Further Improvements and Applications. Talanta, 64, 1151-1159. http://dx.doi.org/10.1016/j.talanta.2004.03.068

[3] Bedioui, F. and Griveau, S. (2013) Electrochemical Detection of Nitric Oxide: Assessment of Twenty Years of Strategies. Electroanalysis, 25, 587-600. http://dx.doi.org/10.1002/elan.201200306

[4] Hetrick, E.M. and Schoenfisch, M.H. (2009) Analytical Chemistry of Nitric Oxide. Annual Review of Analytical Chemistry, 2, 409-433. http://dx.doi.org/10.1146/annurev-anchem-060908-155146

[5] Saldanha, C., Almeida, J.P.L. and Silva-Herdade, A.S. (2014) Application of a Nitric Oxide Sensor in Biomedicine. Biosensors, 4, 1-17. http://dx.doi.org/10.3390/bios4010001

[6] Trevin, S., Bedioui, F. and Devynck, J. (1996) Electrochemical and Spectrophotometric Study of the Behavior of Electropolymerized Nickel Porphyrin Films in the Determination of Nitric Oxide in Solucion. Talanta, 43, 303-311. http://dx.doi.org/10.1016/0039-9140(95)01752-6

[7] Allen, B.W., Piantadosi, C.A. and Coury, L.A. (2000) Electrode Materials for Nitric Oxide Detection. Nitric Oxide: Biology and Chemistry, 4, 75-84. http://dx.doi.org/10.1006/niox.2000.0273

[8] Berisha, L.S., Kalcher, K., Maloku, A., Andoni, E. and Arbneshi, T. (2013) Electrocatalytic Oxidation of Nitric Oxide at Carbon Paste Electrode Modified with Chromium (III) Oxide. Journal of Advances in Chemistry, 5, 792-799. http://cirworld.com/index.php/jac/article/view/3183

[9] Pubudu, W. and Peiris, M. (2009) New Generation of Electrochemical Sensors for Nitric Oxide: Ruthenium/CarbonBased Nanostructures and Colloids as Electrocatalytic Platforms. Ph.D. Dissertation, Cleveland State University. http://rave.ohiolink.edu/etdc/view?acc_num=csu1283257971

[10] Krylov, A.V. and Lisdat, F. (2007) Nickel Hexacyanoferrate-Based Sensor Electrode for the Detection of Nitric Oxide at Low Potentials. Electroanalysis, 19, 23-29. http://dx.doi.org/10.1002/elan.200603668.

[11] Casero, E., Pariente, F. and Lorenzo, E. (2003) Electrocatalytic Oxidation of Nitric Oxide at indium hexacyanoferrate Film-Modified Electrodes. Analytical and Bioanalytical Chemistry, 375, 294-299. http://dx.doi.org/10.1007/s00216-002-1650-y

[12] Friedemann, M.N., Robinson, S.W. and Gerhardt, G.A. (1996) o-Phenylenediamine-Modified Carbon Fiber Electrodes for the Detection of Nitric Oxide. Analytical Chemistry, 68, 2621-2628. http://dx.doi.org/10.1021/ac960093w

[13] Chen, X., XIe, P., Tian, Q. and Hu, S. (2006) Amperometric Nitric Oxide Sensor Based on Poly (Thionine)/Nafion-Modified Electrode and Its Application in Monitorin Nitric Oxide Release from Rat Kidney. Analytical Letters, 39, 1321-1332. http://dx.doi.org/10.1080/00032710600666438

[14] Wu, F.H., Zhao, G.C. and Wei, X.W. (2002) Electrocatalytic Oxidation of Nitric Oxide at Multi-Walled Carbon Nanotubes Modified Electrode. Electrochemistry Communications, 4, 690-694. http://dx.doi.org/10.1016/S1388-2481(02)00435-6

[15] Gan, X., Liu, T., Hu, X. and Li, G. (2004) An Electrochemical Biosensor for Nitric Oxide Based on Silver Nanoparticles and Hemoglobin. Analytical Sciences, 20, 1271-1275. http://dx.doi.org/10.2116/analsci.20.1271

[16] Garjonyte, R. and Malinauskas, A. (1999) Operational Stability of Amperometric Hydrogen Peroxide Sensors, Based on Ferrous and Cooper Hexacyanoferrates. Sensors and Actuators B, 56, 92-97. http://dx.doi.org/10.1016/S0925-4005(99)00161-6

[17] Pauliukaite, R., Ghica, M.E. and Brett, C.M.A. (2005) A New, Improved Sensor for Ascorbate Determination at Cop- 
per Hexacyanoferrate Modified Carbon Film Electrodes. Analytical and Bioanalytical Chemistry, 381, 972-978. http://dx.doi.org/10.1007/s00216-004-2958-6

[18] Ojani, R., Raoof, J.B. and Norouzi, B. (2008) Cu(II) Hexacyanoferrate (III) Modified Carbon Paste Electrode; Application for Electrocatalytic Detection of Nitrite. Electroanalysis, 20, 1996-2002. http://dx.doi.org/10.1002/elan.200804278

[19] Pauliukaite, R., Florescu, M. and Brett, C.M.A. (2005) Characterization of Cobalt- and Copper HexacyanoferrateModified Carbon Film Electrodes for Redox-Mediated Biosensors. Journal of Solid State Electrochemistry, 9, 354-362. http://dx.doi.org/10.1007/s10008-004-0632-8

[20] Wang, J., Zhang, X. and Prakash, M. (1999) Glucose Microsensors Based on Carbon Paste Enzyme Electrodes Modified with Cupric Hexacyanoferrate. Analytica Chimica Acta, 395, 11-16. http://dx.doi.org/10.1016/S0003-2670(99)00306-2

[21] Nims, R.W., Darbyshire, J.F., Saavedra, J.E., Christodoulou, D., Hanbauer, I., Cox, G.W., Grisham, M.B., Laval, J., Cook, J.A., Krishna, M.C. and Wink, D.A. (1995) Colorimetric Methods for the Determination of Nitric Oxide Concentration in Neutral Aqueous Solutions. Methods (A Companion to Methods Enzymology), 7, 48-54. http://dx.doi.org/10.1006/meth.1995.1007 